$\begin{array}{cl} & \\ \text { INTERNATIONAL CRIMINAL LAW REVIEW } & \begin{array}{l}\text { International } \\ \text { Criminal Law } \\ \text { Review }\end{array} \\ 19(2019) 1-30 & \text { brill.com/icla }\end{array}$

\title{
Virtue Ethics, Criminal Responsibility, and Dominic Ongwen
}

\author{
Renée Nicole Souris 3 \\ Department of Justice, Law and Criminology, American University, $\quad 4$ \\ Washington, DC, US \\ souris@american.edu 6
}

\begin{abstract}
In this article, I contribute to the debate between two philosophical traditions- the 8 Kantian and the Aristotelian - on the requirements of criminal responsibility and the 9 grounds for excuse by taking this debate to a new context: international criminal law. 10 After laying out broadly Kantian and Aristotelian conceptions of criminal responsibil- 11 ity, I defend a quasi-Aristotelian conception, which affords a central role to moral de- 12 velopment, and especially to the development of moral perception, for international 13 criminal law. I show than an implication of this view is that persons who are substan- 14 tially and non-culpably limited in their capacity for ordinary moral perception warrant $\quad 15$ an excuse for engaging in unlawful conduct. I identify a particular set of conditions 16 that trigger this excuse, and then I systematically examine it as applied to the contro- $\quad 17$ versial case of former-child-soldier-turned leader of the Lord's Resistance Army, Domi- 18 nic Ongwen, who is currently at trial at the International Criminal Court.
\end{abstract} (1)

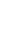
(1)

Keywords

criminal responsibility - international criminal law - virtue ethics - moral perception 21

- child soldiers - International Criminal Court (ICC) - Dominic Ongwen 22

In recent decades, virtue ethicists have brought renewed attention to the 24 importance of moral education of the emotions, and the capacity for moral $\quad 25$

(C) KONINKLIJKE BRILL NV, LEIDEN, 2019 | DOI:10.1163/15718123-01903005 
26 perception, to ethical life. ${ }^{1}$ This has also been seen in legal theory, particularly 27 in recent theorising about criminal responsibility and excuse. Multiple schol28 ars have put forth what may be broadly described as Aristotelian accounts of criminal responsibility, in their efforts to challenge the more Kantian approaches to criminal responsibility that long dominated Anglo-American legal thought and practice. ${ }^{2}$ In this article, I contribute to the debate between Kantian and Aristotelian camps by taking the discussion to a new domain, that of international criminal law. Specifically, I seek to show that the case for a quasi-Aristotelian conception of criminal responsibility and excuse, ${ }^{3}$ which affords a central role to moral development, and especially to the development of moral perception, is stronger on the international level than it, arguably, is on the domestic level. ${ }^{4}$

Under the quasi-Aristotelian conception of criminal responsibility and excuse that I draw on in this article, a person is excused from criminal responsibility if she lacked either the capacity or the fair opportunity to choose to obey the law, where this includes the capacity for practical reason, as well as certain moral capacities, and a fair opportunity nor rcise these capacities. One implication of this view is that certain forms o fective moral development ground an excuse from criminal responsibility for criminal conduct. One such excuse, which I call the 'harmed moral perception excuse', figures prominently in my article. I situate this excuse within the long tradition of virtue ethics beginning with Aristotle, but I argue for it in a new context, that is, in the context of

1 E.g., Rosalind Hursthouse, On Virtue Ethics (Oxford University Press, New York, 1999); Laurence Blum, Moral Perception and Particularity (Cambridge University Press, Cambridge, 2004); Eve Rabinoff, Perception in Aristotle's Ethics (Northwestern University Press, Evanston, IL, 2018). See also the work of Martha Nussbaum, who does not endorse the category of virtue ethics, but whose work nonetheless highlights the role of emotions similar to virtue ethicists: Martha Nussbaum, 'Virtue ethics: a misleading category?', 3(3) The Journal of Ethics (1999) 163-201; Martha Nussbaum, Hiding from Humanity: Disgust, Shame, and the Law (Princeton University Press, Princeton, 2004).

2 Peter Arenella, 'Character, Choice, and Moral Agency: The Relevance of Character to Our Moral Culpability Judgments', 7(2) Social Philosophy and Policy (1990) 59-83; Dan N. Kahan and Martha C. Nussbaum, 'Two Conceptions of Emotions in Criminal Law', 96(2) Columbia Law Review (1996) 269-374; John Gardner, 'The Gist of Excuses', 1 Buffalo Criminal Law Review (1998) 575-598; Kyron Huigens, 'On Aristotelian Criminal Law: A Reply to Duff', 18(2) Notre Dame Journal of Law \& Public Policy (2004) 465-499.

3 I describe the view I defend as a 'quasi'-Aristotelian account on the grounds that it does not offer a full account of virtue and does not consider virtue per se as central to criminal responsibility.

4 While I am largely persuaded by aspects of the Aristotelian view for domestic law, it is not my intention to argue directly for it in this article. For defences of the Aristotelian view for domestic law, see supra note 2 . 
international criminal law. There is a strong case in favour of the harmed moral perception excuse under international criminal law because international crimes are often carried out in the environment of armed conflict, which is known to burden the exercise of an ordinary person's agential capacities of practical reason and moral perception, and because international crimes are fundamentally moral wrongs.

My argument proceeds as follows. Section 2 frames the analysis. I begin by describing the Kantian conception of criminal responsibility, which figured prominently in legal theory and practice until a renewed interest in virtue ethics a few decades ago revived Aristotelian ideas (regarding the relevance of emotions, moral education, and character to ethical judgment) and integrated them into theories about criminal responsibility and excuse. Here, I present a quasi-Aristotelian conception of criminal responsibility and excuse, which is anchored in a character conception of moral agency, but that identifies choice as the intentional object of criminal responsibility. Then I explain how this conception supports the harmed moral perception excuse. In Section 3, I argue for recognition of the harmed moral perception excuse under international criminal law, in light of the extraordinary environments in which international crimes typically occur, and the moral nature of international crimes. In Section 4, I identify four conditions for the application of the harmed moral perception excuse, and a plausible application of it to the prominent contemporary case of Dominic Ongwen, the former-child-soldier-turned-leader of the Lord's Resistance Army (LRA), who is currently on trial at the International Criminal Court (ICC). Lastly, in Section 5, I summarise my argument, respond to a possible lingering objection, and offer concluding remarks.

What has been described as a Kantian approach to criminal responsibility stems from the philosophical tradition beginning with Augustine, which takes free will as the ultimate condition of responsible agency and finds a modern expression in the legal thought of H.L.A. Hart, as well as in some writings of contemporary legal theorist, Michael Moore. In his moral writings, Kant held that the will is the locus of our moral agency, and the moral worth of an action comes from the fact that is done out duty alone, and out of respect for the moral law, unmixed by inclination. ${ }^{5}$ Human law, as Kant explains in the 'Doctrine

5 Immanuel Kant, Grounding for the Metaphysics of Morals: On a Supposed Right to Lie because of Philanthropic Concerns, James W. Ellington, trans., $3^{\text {rd }}$ ed.(Hackett, Indianapolis/ Cambridge, 1993). 
of Right' in Metaphysics of Morals, however, is distinct from the moral law, and its demands are primarily external. ${ }^{6}$ Human law does not demand conformity of the will with the law out of respect for the law, as does the moral law, but it demands conformity of conduct. ${ }^{7}$ This does not mean that the will is irrelevant to human law, however. While it does not really matter why we follow human law, it matters why we break it. For Kant, the criminal law implicitly recognises that our will may be overcome by the demanding nature of certain circumstances, and in such cases, we cannot justly be punished for acting contrary to the law. ${ }^{8}$

Scholars after Kant developed Kant's ideas about the will, rationality, and autonomy to construct their own accounts of criminal responsibility and excuse. Hart argued that the excuses deal with the distribution of punishment, based on principles of justice and respect for individual autonomy. ${ }^{9}$ This led him to endorse the view of excuses that 'what is crucial is that those whom we punish should have had, when they acted, the normal capacities, physical and mental, for abstaining from what [the law] forbids, and a fair opportunity to exercise these capacities'.10

In the context of a highly relevant debate between the Kantian and Aristotelian camps in the 199os, Moore further developed Hart's view and put forth a version of what has been called the 'choice theory' of responsibility and excuse. Moore explained that Hart's criteria in the above quotation contains two requirements, one which concerns the 'equipment' of the actor, and the other which concerns his or her 'situation'.11 In his examination of these

Immanuel Kant, 'Doctrine of Right', in Mary Gregor (ed.), The Metaphysics of Morals (Cambridge University Press, Cambridge, 1996).

Allan Wood and Paul Guyer debate the relation between law and morality in Kant's thought. See Allan Wood, 'The Final Form of Kant's Practical Philosophy', in Mark Timmons (ed.), Kant's Metaphysics of Morals: Interpretative Essays (Oxford University Press, New York, 2002), pp. 1-22; Paul Guyer, 'Kant's Deductions of the Principles of Right', in Mark Timmons (ed.), Kant's Metaphysics of Morals: Interpretative Essays (Oxford University Press, New York, 2002), pp. 23-64.

In 'Doctrine of Right', supra note 6, Kant writes the following of a shipwrecked man who throws another man overboard to save his life: 'An act of violent self-preservation, then, ought not to be considered as altogether beyond condemnation (inculpabile); it is only to be adjudged as exempt from punishment (impunibile)', p. 28.

9 H.L.A. Hart, 'Prolegomenon to the Principles of Punishment', 6o Proceedings of the Aristotelian Society (1959-1960) 1-26.

10 H.L.A. Hart, Punishment and Responsibility: Essays on the Philosophy of Law (Oxford University Press, New York, 2008), p. 152.

11 Michael Moore, 'Choice, Character, and Excuse', 7(2) Social Philosophy and Policy (1990) - 
requirements, Moore held the following claims also to be true: the capacity for choice under the criminal law is made possible by practical reason, emotions do not incapacitate choice, ${ }^{12}$ and though it may be more difficult for persons to choose to obey the law if they cannot do so for moral reasons, they are not deprived of the fair opportunity to choose to do so by virtue of this difficulty. ${ }^{13}$

In an influential essay on emotion and criminal law, Dan Kahan and Martha Nussbaum argued that the Kantian-based conception of criminal responsibility embraces a problematic mechanistic conception of emotion, under which emotions are

forces more or less devoid of thought or perception' and 'impulses or surges that lead [a] person to action without embodying beliefs, or any way of seeing the world that can be assessed as correct or incorrect, 116 appropriate or inappropriate. ${ }^{14}$

On this view, emotions are external forces that cannot be educated, and must be tamed. Kahan and Nussbaum defended an alternative conception, which they referred to as the evaluative conception of emotion, under which emotions 'do embody beliefs and ways of seeing, which include appraisals or evaluations of the importance or significance of objects or events', which, in turn, can 'be evaluated for their appropriateness or inappropriateness'. 15

Contemporary work in moral psychology largely supports the evaluative conception, and shows that although we may experience the affective component of emotions as if the emotions themselves are happening to us, mature emotional development consists in the ability to manage or regulate our emotions. ${ }^{16}$ The development of emotion regulation (or emotional intelligence) is partly a function of neurological development ${ }^{17}$ and partly a function of

12 Ibid., pp. 559-56o. Moore is also a compatibilist, so even if emotions are external, they do not negate choice, ibid., pp. 553-554.

13 Ibid., and surrounding discussion in Moore's text.

14 Kahan and Nussbaum, supra note 2, pp. 277-278.

15 Ibid., p. 278.

16 Benoit Monin, Jennifer S. Beer, and David A. Pizzaro, 'Deciding Versus Reacting: Conceptions of Moral Judgment and the Reason-Affect Debate', 11(2) Review of General Psychology (2007) 99-111.

17 Antonio Damasio, Descartes' Error: Emotion, Reason, and the Human Brain (Macmillan, London, 1996). 
social development. ${ }^{18}$ In addition, emotions influence our practical reasoning, ${ }^{19}$ shape our moral perception, and thus aid (or impair) our decision-making. ${ }^{20}$ Consequently, disruption to emotional development creates a risk of harm to a person's practical reasoning ability ${ }^{21}$ and to his or her moral development. ${ }^{22}$

The Kantian-based version of the choice theory does not directly attend to the role that development plays in our becoming responsible beings in the world, or how certain experiences can deteriorate our agential capacities. Writing from an Aristotelian perspective, Jonathan Jacobs introduces the term 'coercive corruption' to describe how certain environments can habituate a person toward vice, in a way that powerfully impacts his or her character development. ${ }^{23}$ This idea is particularly relevant to the present discussion, insofar as the environments that are most 'successful' in habituating persons toward vice may also be those over which persons typically have the least control.

Imagine, for example, a young man, $D$, who, grew up enduring systematic coercion to commit criminal acts, was socialised by persons far more powerful than him into values radically at odds with those of law-abiding society, and kept isolated from anyone who could challenge $D$ 's treatment without suffering serious harm. Suppose, further, that $D$ 's formative adolescent years were spent learning how to stay alive through crime, and by the time he is a young adult, he has embraced crime as a way of life. Has $D$ been coercively corrupted, or habituated by vice, making him inculpable for his present inclinations towards criminality? Or does $D$ consent to a criminal life? Does it matter that $D$ comes from a 'rotten social background' 24 in judging whether he is criminally responsible for his adult crimes? If 'perpetrators can experience their crimes as trauma', that causes them 'psychological injury... which can result in particular

18 Laurence Steinberg, 'Cognitive and affective development in adolescence', 9(2) Trends in Cognitive Science (February 2008) 69-73.

19 Patricia Greenspan, 'Practical Reasoning and Emotion', in Alfred R. Mele and Piers Rawling (eds.), The Oxford Handbook of Rationality (Oxford University Press, Oxford, 2014) pp. 206-221. June Price Tangney, Jeff Stuewig, and Debra J. Mashek, 'Moral Emotions and Moral Behavior', $5^{8}$ Annual Review of Psychology (2007) 345-372.

21 Damasio, supra note 17.

22 Tagney et al., supra note 20.

23 Jonathan Jacobs, 'Character, Punishment, and the Liberal Order', in Alberto Masala and Jonathan Webber (eds.), From Personality to Virtue: Essays on the Philosophy of Character (Oxford University Press, Oxford, 2016), pp. 9-34.

24 Richard Delgado, 'Rotten Social Background: Should the Criminal Law Recognize a Defense for Severe Environmental Deprivation', 3(9) Law \& Inequality: A Journal of Theory and Practice (1985) 9-9o. 
adverse physical, social, emotional consequences, ${ }^{25}$ how would this developmental fact matter to judging $D$ 's adult culpability for criminal acts that no one coerced him to commit?

It has sometimes been held, and is often assumed, by proponents of the Kantian view, that persons are always responsible for their present characters, even if they have been exposed to traumatic experiences or corrupt moral teachings, because, at some point, they consented to becoming the persons they are. ${ }^{26}$ However, it is not always reasonable to expect persons to be capable of exercising the kind of reflective self-control that would allow them to evaluate their moral characters, revise them, and alter the ends their characters incline them to pursue. It may also be true, in some cases, that those most in need of revision to their moral characters are least able to perceive the need for revision, through no fault of their own.

Legal theorists have recently turned to virtue ethics to reconsider the role of character, the emotions, and moral development to criminal responsibility, and to use ideas from virtue ethics to make sense of difficult cases like D's. Beginning with a brief discussion of Aristotelian ethics, I highlight the role of moral perception in ethical life, and how it can figure into a conception of criminal responsibility. Then, I lay out the harmed moral perception excuse, and, in the next section, I show there are compelling reasons to recognise it under international criminal law. ${ }^{27}$

For Aristotle, we are responsible for our voluntary actions, and our characters, insofar as our characters are under our rational control and created through our voluntary actions. ${ }^{28} \mathrm{He}$ recognised that none of us is fully responsible for who we are, as habit formation and character development begin in

25 Saira Mohamed, 'Of Monsters and Men: Perpetrator Trauma and Mass Atrocity', 115(5) Columbia Law Review (2015) p. 1162.

26 Scanlon and Darwall embrace some version of this view. Scanlon holds that persons need the capacity to see the force of moral reasons in order to be fairly held responsible but carves out an exception for persons who simply 'resist changing what they can', in Thomas Scanlon, What We Owe To Each Other (Belknap Press of Harvard University Press, Cambridge, MA, 1998) pp. 282-283. Darwall accepts the description that psychopathy develops from 'prior willful choices to reject the moral community'; Stephen Darwall, Second Personal Standpoint (Harvard University Press, Cambridge, MA, 2006) pp. 88-9o.

27 There is a related literature on whether individual ignorance excuses for criminal and institutional wrongdoing, but as it typically takes a broader view of ignorance than I am concerned with in this article, I do not focus on it here. For an influential recent book, see Doug Husak's Ignorance of Law (Oxford University Press, New York, 2016).

28 Aristotle, Nicomachean Ethics, trans. by Terence Irwin, Second Edition (Hackett, Indianapolis, 1999), Book III. 
youth when we lack practical reasoning. As practical reason develops, we acquire the ability to evaluate ends and select means to achieve them, but because our ability to do so is greatly influenced by our upbringing, Aristotle emphasised the importance of providing youth with good examples and instilling proper habits through practice.

While Aristotle believed that virtue and vice are both voluntary, and that we are justly held responsible for our characters where they are developed through our voluntary actions, he does acknowledge that some people become morbid or brutal by habituation, such as those who have been abused since childhood, and that such persons are 'outside the limits of vice'. ${ }^{29}$ Here, Aristotle gestures to the idea that some people are not justly held responsible for their characters, insofar as it is unreasonable to say that their characters were formed through voluntary actions. ${ }^{30}$ This, I think, is similar to the kind of coercive corruption to which Jacobs refers, and highlights the fact that we are social animals, just as much as rational ones. ${ }^{31}$ As social animals, we develop our habits, which constitute our characters, not alone, but through our experiences with others.

Aristotle attends closely to the formation of habits of action and feeling in his ethical writings, in recognition that these habits shape how we perceive the world. Eve Rabinoff has argued in a recent book that, for Aristotle, perception is the key to virtue, and that perception is equipped to discern morally salient particulars in one's circumstances. ${ }^{32}$ In a passage that echoes recent findings in moral psychology on the importance of emotions to acting morally, Rabinoff writes:

Being fully prepared to act virtuously by having all the principles and being able to enact them just is not the same as actually acting virtuously; knowing what to do is not the same thing as doing it, and what makes the difference must come from the perception of particular, present circumstances. $^{33}$

29 Aristotle, supra note 28, Book viI, Chapter 4, 1149a.

30 Perhaps in the case of the morbid or brutal by habituation who are coerced into vice, such persons formed their characters through what Aristotle calls 'mixed actions', which are part voluntary, as they are chosen, but part involuntary, insofar as no one would choose them for their own sakes. Ibid. Book III, Chapter 1, 1113a-1135b.

31 Jacobs makes a similar point about our dual social and rational nature, supra note 23.

32 Rabinoff, supra note 1.

33 Ibid., p. 6. 
Rabinoff connects her reflections on ethical perception in Aristotle with re- 209 cent work by Lawrence Blum, who also maintained that: '[o]ne's moral behav- 210 ior does not issue simply from one's rational reflection upon it, but importantly 211 from one's sensitivity and way of responding perceptually and emotionally to $\quad 212$ one's particular circumstances', ${ }^{34}$ For Blum, moral perception plays a key role $\quad 213$ in our ability to choose to do the right thing, as it bridges the gap from abstract 214 moral rules or principles to particular situations, and allows us to see ourselves $\quad 215$ living in a moral world where abstract moral rules and principles apply to the $\quad 216$ $\begin{array}{ll}\text { messy affairs of real life. } & \\ & \end{array}$

Martha Nussbaum, John Gardner, Kyron Huigens, and Peter Arenella have 218 each put forth accounts of criminal responsibility that draw on some of the 219 central ideas of Aristotle's ethics, in explaining, for instance, the importance 220 of emotions and character development to questions of culpability. ${ }^{36}$ Among 221 them, Arenella's is the most relevant for my purposes here. The basic idea of 222 Arenella's view is that the capacity and fair opportunity to choose to obey the 223 law includes not only practical reasoning ability, but also a basic moral com- 224 petence that allows persons to grasp, perceive, and act on the moral (and not 225 simply the prudential) reasons for choosing to obey the law, as well as the fair $\quad 226$ opportunity to develop practical reason and this moral competence. ${ }^{37} \quad 227$

Arenella develops a kind of choice theory that is anchored in a character $\quad 228$ conception of moral agency, under which choice is the intentional object of 229 liability, but where the opportunity to develop a certain kind of character is a 230 condition of criminally responsible agency. He argues that, because the crimi- 231 nal law derives a large part of its force from moral norms, persons who lack the 232 capacity or fair opportunity to choose to obey the law for moral reasons are $\quad 233$

34 Ibid., p. 9 .

35 Blum, supra note 1; see also Lawrence Blum, 'Moral Perception and Particularity', Ethics 101 (1991) 701-725.

$36 \quad$ Supra note 2.

37 Arenella, supra note 2; see also Antony Duff, 'Virtue, Vice, and Criminal Liability: Do We Want an Aristotelian Criminal Law?', 6(1) Buffalo Law Review (April 2002) 147-184. Similar to Arenella, Antony Duff argues that criminally responsible choice requires the normative capacities of a reasonable person to have a proper regard for the law and the values it protects, though he rejects the idea that we want an Aristotelian criminal law. Duff offers several reasons for this, though most are aimed at the kind of character-based theory of criminal responsibility put forth by Michael Bayles, which makes character the intentional objects of liability. Because Arenella's view makes choice the intentional object of liability, this objection does not apply to his view. In a reply article to Duff, Kyron Huigens also argues that Duff's view is more consistent with an Aristotelian view than he supposes. See Huigens, supra note 2. 
at an unfair disadvantage in knowing what their obligations are, and in their ability to make the choice to fulfil them. Arenella refers to the basic moral competence required for criminally responsible choice as 'moral responsiveness ". and it includes the following set of capacities: the capacity to cognitively gravp the moral norms that support the law's prohibitions, the capacity to exercise moral judgment about how those norms apply to particular contexts (or, what I call moral perception), and the motivational capacity to use the applicable norms as a basis for acting.

Furthermore, Arenella argues that unless a person has been provided socially created opportunities to develop these capacities, which he or she was genuinely capable of taking advantage of, it is not a culpable failure if a person has not developed these capacities on his or her own. One's background is not itself an excusing condition, but one's background can, for example, help mould a person's character in a way that deprives him or her of the capacity or fair opportunity to perceive where the moral norms that support the criminal law apply in particular situations. And, insofar as the criminal law is held to derive a large part of its force from morality, the capacity to perceive where the moral norms that support the criminal law apply in particular situations is required for persons to have a fair opportunity to choose to obey it. This means that persons who, through no fault of their own, have a substantial limitation to their capacity to perceive where the moral norms that support the law apply in particular situations, have been deprived of the fair opportunity to choose to obey the law. I call this th red this the harmed moral perception excuse. As both the Kantian and Aristotelian camps agree, persons who break the law, but who have been deprived of the fair opportunity to choose to obey it, warrant an excuse from criminal responsibility.

\section{Defending the Quasi-Aristotelian Conception under International Criminal Law}

A supporter of the Kantian-based conception of the choice theory could object, hov ev $r$, to the quasi-Aristotelian conception of criminal responsibility and excuse laid out above, on the grounds that the capacity of practical reason is sufficient to provide persons the fair opportunity to choose to obey the law, thus making moral capacities largely irrelevant. As such, she might draw on basic ideas of legal positivism to argue that laws are social rules, whose validity rests on social facts, not morality. She might add that, while some people

38 Arenella, supra note 2, p. 82. 
may choose to obey the law because they perceive the moral force of the law, the existence of valid law itself provides people with sufficient (or at least sufficiently strong) prudential reasons for action, thus rendering moral reasons unnecessary.

In this section, I respond to this objection by examining it in relation to international criminal law. My aim is to show that the underlying logic of the objection rests on sociological and philosophical assumptions about the context and nature of law that do not account for salient features of international criminal law, which undermines the force of the objection in the context of international law. My argument proceeds in two parts. First, I focus on the context in which international criminal law operates. Secondly, I focus on the nature of international crimes. A main implication of my argument is that, given the extraordinary environments in which international crimes typically occur, and the moral nature of international crimes, there is a strong case for the quasi-Aristotelian conception of criminal responsibility, and the harmed moral perception excuse that is derived from it, under international criminal law.

The influential legal positivist, H.L.A. Hart, argued that, in a legal system, citizens typically follow the law because they accept the rules of the system. ${ }^{39}$ This acceptance follows from the fact that the law supports the basic order of society, and with respec the criminal law, the fact that disobedience is typically met with sanction. In a functioning legal system, where established legal institutions maintain order through a largely settled and generally accepted system of rules, it is reasonable to expect most persons in society, most of the time, to conform their conduct to the basic rules of the criminal law without reflecting (morally) on it. ${ }^{40}$

Even a positivist can agree, however, that the environments in which international crimes typically occur are more forcibly limited and hostile than the

39 H.L.A. Hart, The Concept of Law (Clarendon Law Series, Oxford University Press, Oxford, 1961).

40 In this sense, people develop a sort of habitual obedience to the law, even if the idea of continuing habit cannot account for the concept of following a rule. Hart argues that our legal obligations do not exhaust our obligations: our legal obligations to obey unjust laws can be trumped by our moral obligations to disobey them. For this point, see H.L.A. Hart, 'Positivism and the Separation of Law and Morals', 71(4) Harvard Law Review (1958) 593-629.

41 Perhaps the closest domestic parallel in a domestic legal system is the environment created by some extreme gangs, where the 'law of the street' rather than the criminal law are the accepted rules of the game, so to speak. Even so, gangs are typically not nearly as isolated from the wider realms of law-abiding society as are the armed groups in Africa that 
of these differences is built into the Rome Statute, which is the treaty that created the International Criminal Court (ICC or Court) and serves as its governing body of law. The ICC only acquires jurisdiction over cases where states are unable or unwilling to prosecute the crimes themselves. ${ }^{42}$ This means that the crimes that fall under the jurisdiction of the ICC occur in states that are failing in some fundamental way, by carrying out the crimes themselves, being complicit in them, or by failing to prosecute them. ${ }^{43}$

Moreover, because the ICC is designed with complementary jurisdiction to states, ${ }^{44}$ this body of international criminal law operates more directly in the affairs of states than in the lives of ordinary people. ${ }^{45}$ Relative to the role played by the threat and fear of sanction over the lives of ordinary citizens in a functioning state, the role played by the threat and fear of sanction under international criminal law is much weaker. States operate as intermediaries between the ICC and ordinary people, making the expectable benefits the ICC can offer, and the expectable burdens it can impose, more certain and immediate for states than for individuals.

The ICC has jurisdiction over the 'most serious crimes that concern the international community as a whole which has been interpreted to empower the Court to prosecute those most icsponsible for atrocities, and to target the highest-ranking perpetrators for prosecution. ${ }^{47}$ Yet, the highest-ranking perpetrators typically have considerable power that insulates them from the actual

are the subject of many ICC investigations, and this isolation is relevant to our culpability judgments.

42 Rome Statute, Article 17.

43 For a discussion on the ethics of lawfare and whether the first two ICC were instances of lawfare, see K.J. Fisher and C.G. Stefan, 'The Ethics of International Criminal 'Lawfare', 16(2) International Criminal Law Review (2016) 237-257.

44 The Preamble to the Rome Statute '[e]mphasiz[es] that the International Criminal Court established under this Statute shall be complementary to national criminal jurisdictions'. My ideas here have been influenced by Allan Buchanan's recent criticism of the attempt by John Tasioulas to offer a Razian account of international law. See Allan Buchanan, 'The Legitimacy of International Law', in Samantha Besson and John Tasioulas (eds.), The Philosophy of International Law (Oxford University Press, Oxford, 2010), pp. 79-96; see also John Tasioulas, 'The Legitimacy of International Law', in Besson and Tasioulas (eds.), ibid., pp. 97-116 (emphasis added in text).

46 Rome Statute, Preamble.

47 The question of rank has been considered an issue of admissibility at the ICc. Article 17 of the Rome Statute identifies requirements on admissibility at the ICC. Article 17 (d) articulates the requirement that a case be deemed inadmissibility if 'it is not of sufficient gravity to justify further action by the Court'. Questions have been raised about the importance of a perpetrator's rank to the gravity threshold. For a discussion of the relevant jurisprudence, 
reach of the Court. ${ }^{48}$ Some say that this explains why the ICC has prosecuted leaders of rebel groups for international crimes, who typically have less power than state officials. ${ }^{49}$

While lower-ranking perpetrators may be more affected by the threat of sanction by the Court than high-ranking perpetrators, it is unlikely that the threat of sanction at the ICC offers greater deterrent value (and thus prudential reason for action) than the threats these individuals face for disobeying their superiors, or the expected costs to their security in relinquishing violence as a means of protection and power. The Rome Statute identifies 30 years as a maximum sentence pursuant to a conviction, absent exceptional circumstances. The first defendant convicted at the ICC, Congolese war criminal Thomas Lubanga Dyilo, received a sentence of 14 years. ${ }^{50}$ Other sentences imposed by the Court have been similar. If we compare these sentences with the fact that disobedience of one's superiors inside the extreme armed groups in Africa that have been the subject of some ICC investigations is typically met with credible and imminent harm to one's bodily security or even death, the prospects of classical deterrence through the ICC are weak. A person facing credible and imminent threats of death or serious bodily harm for disobedience is unlikely to see the uncertain threat of a less severe sanction from a distant court in The Hague as offering prudential reason to choose to obey the law, assuming he or she even knows what the law is.

Because the prudential reasons to choose to obey the law are so weak under international law, perhaps a positivist could agree that the capacity to perceive the moral reasons to choose to obey the law are more important under this body of law. Of course, a positivist may respond that the foregoing argument about the weaker deterrent force of international criminal law indirectly supports the argument that we need better enforcement of international criminal law, rather than more excuses from it. A positivist could contend that, through

see Metgumi Ochi, 'Gravity Threshold before the International Criminal Court: An Overview of the Court's Practice', International Crimes Database, ICD Brief (January 2016).

Consider, for example Pre :ident Omar al-Bashir of Sudan, who was indicted for orchestrating genocide in Darfur by the ICc pursuant to a United Nations Security Council referral. Because of his power and influence, al-Bashir remains at large. Prosecutor v. Omar Hassan Ahmad Al Bashir. ICC-02/05-01/09.

49 This has sometimes been said of the ICc's first case against Congolese war criminal, Thomas Lubanga Dyilo. See William A. Schabas, 'Prosecutorial Discretion v. Judicial Activism at the International Criminal Court', 6(4) Journal of International Criminal Justice (2008) 731-761; and Margaret M. deGuzman, 'Gravity and the Legitimacy of the International Criminal Court', Fordham International Law Journal (2009) 1400-1465. 
more certain and severe sanctions, international criminal law has a better chance of becoming accepted and established, and through better enforcement, it can provide strong prudential reasons to conform one's conduct to it.

Yet, this argument is problematic for two reasons. First, this approach could complicate the complementarity regime upon which the Court is built. While a functioning domestic legal system provides deterrent value by threatening and imposing classically coercive sanctions, the ICC is designed as a court of last resort, which means that a high number of ICC convictions would not necessarily signal that the Court is fulfilling its mandate to end impunity for mass atrocities. Rather, the adoption of the Rome Statute itself-in whole or part-into domestic legal systems would better illustrate this result, as it would show that states are taking seriously their primary responsibility to prevent atrocities within their borders. ${ }^{51}$ In a systematic analysis of the deterrent capacity of the ICC, Christopher W. Mullins and Dawn L. Rothe argue that the Court's traditional deterrent capacity is weak, but they conclude that this does not undermine the Court's mission or value, as the Court's direct contributions to deterrence may be primarily symbolic. ${ }^{2}$ The ICC's expressive capacity can allow the ICC to serve as a check on states, and indirectly contribute to deterrence. ${ }^{53}$

Secondly, the Court risks delegitimising itself if it lacks integrity between its practices and the moral norms upon which its authority depends. If the ICC seeks to establish itself coercively, then it puts a stamp of approval on this sort of conduct for states. David Luban has argued that the primary purpose of international criminal law is to project norms, ${ }^{54}$ and this means that the practices that the Court develops will set standards for the international community. Because of the close connection between law and morality on the

51 Lisa J. Laplante, 'The Domestication of International Criminal Law: A Proposal for Expanding the International Criminal Court's Sphere of Influence', 43 John Marshall Law Review (2010) 635-680.

52 Christopher W. Mullins and Dawn L. Rothe, "The Ability of the International Criminal Court to Deter Violations of International Criminal Law: A Theoretical Assessment', 10(5) International Criminal Law Review (2010) 771-786.

53 Nidal Nabil Jurdi makes a similar point, that the 'complementarity regime of the ICC can contribute to the creation of an effective indirect enforcement mechanism among state parties to the Rome Statute on a systematic basis', although writing in 2010, he found the practice of the ICc falling short of the goal. See Nidal Nabil Jurdi, "The Prosecutorial Interpretation of the Complementarity Principle: Does it Really Contribute to Ending Impunity on the National Level?', 10 International Criminal Law Review (2010) 73-96.

54 David Luban, 'Fairness to Rightness: Jurisdiction, Legality, and the Legitimacy of International Criminal Law', in Besson and Tasioulas (eds.), supra note 45, pp. 569-588. 
international level, the ICC has a duty to uphold moral norms that establish its legal authority. With this in view, I now turn to the second part of this section, where I show that the moral nature of international crimes further strengthens the case for the quasi-Aristotelian conception of criminal responsibility and excuse, and for the harmed moral perception excuse that is supported by it.

It is generally agreed that international criminal law derives from jus cogens norms, which are universally binding, regardless of whether they have been given explicit consent. ${ }^{55}$ Jus cogens is Latin for 'compelling law', meaning that 378 these norms have a sort of super-status, which are held to give rise to obligations erga omnes, which is Latin for 'flowing to all'. One example of a jus cogens norm is the prohibition on the wanton killing of innocents. While states and legal scholars debate the content and scope of jus cogens norms, there is consensus that they protect fundamental values from which no derogation is permitted. This view has been embraced by United Nations General Assembly, and, in 2015, was expressed by the Special Rapporteur as follows: '[n]orms of jus cogens protect fundamental values of the international community, are hierarchically superior to other norms of international law and are universally applicable. ${ }^{56}$ In a similar vein, William Schabas writes that:

The idea that there is some common denominator of behaviour, even in 390 the most extreme circumstances of brutal armed conflict, confirms be391 liefs drawn from philosophy and religion about some of the fundamental values of the human spirit. ${ }^{57}$

The sphere of conduct that the Rome Statute identifies as criminal, and especially crimes against humanity and genocide, derives its force from the binding nature of jus cogens norms. In light of this, Ronald Dworkin has argued that the Rome Statute is binding by virtue of its moral force, rather than by the state consent that formed it. ${ }^{58}$ While a positivist might not be willing to say that the

55 M. Cherif Bassiouni, 'International Crimes: Jus Cogens and Obligatio Erga Omnes', 59(4) Law and Contemporary Problems (1996) 63-74.

56 See Draft Conclusion 3, <legal.un.org/ilc/reports/2016/english/chp9.pdf>, accessed 8 February 2019 .

57 William Schabas, An Introduction to the International Criminal Court, $5^{\text {th }}$ ed. (Cambridge University Press, Cambridge, 2017), p. 1.

$5^{8}$ Ronald Dworkin, 'A New Philosophy for International Law', 41(1) Philosophy \& Public Affairs (2013) 
rather than social facts, she could acknowledge that the content of the Statute includes such norms.

'Inclusive legal positivists' acknowledge that morality can be written into the content of the law. ${ }^{59}$ Article 33 of the Rome Statute is one example of a provision that has been interpreted to have moral content, and it a provision that is particularly relevant here. This is because Article 33's 'manifest illegality provision' provides a legal basis for thinking that a basic kind of moral perception is an implicit requirement of criminally responsible agency under the Statute. Article 33 states:

1. The fact that a crime within the jurisdiction of the Court has been committed by a person pursuant to an order of a Government or of a superior, whether military or civilian, shall not relieve that person of criminal responsibility unless:

(a) The person was under a legal obligation to obey orders of the Government or the superior in question;

(b) The person did not know that the order was unlawful; and

(c) The order was not manifestly unlawful.

2. For the purposes of this article, orders to commit genocide or crimes against humanity are manifestly unlawful. ${ }^{60}$

Despite the absence of explicit moral language in the Rome Statute's version of the doctrine, the italicised portion implies that those under its jurisdiction are capable of perceiving where basic moral norms that support the prohibitions on genocide and crimes against humanity apply in practice, in accordance with internationally accepted standards of morality. Similarly, Larry May has argued that: 'ascertaining what is manifest requires the use of moral perception,, ${ }^{61}$ and Mark Osiel also maintains:

The doctrine of manifest illegality... rests on the assumption that every reasonable person possesses a moral sense, endowed by nature or instilled by society, enabling him to identify egregiously wicked conduct as such. The law makes no sense, in other words, unless conventional

59 Wilfrid Waluchow, 'Legal positivism, inclusive versus exclusive', in E. Craig (ed.), Routledge Encyclopedia of Philosophy (Routledge, London, 2001).

6o Rome Statute, Article 33 (emphasis added). For my argument that this applies a fortiori to conduct that constitutes crimes against humanity and genocide, that no one ordered a person to commit, see Renée Nicole Souris, 'Child soldiering on trial: An interdisciplinary analysis of responsibility in the Lord's Resistance Army', 13(3) International Journal of Law in Context (2017) 316-335.

61 Larry May, Crimes against Humanity: A Normative Account (Cambridge University Press, Cambridge, 2005), p. 197. 
morality is sufficient to enable the person of ordinary understanding to identify radically evil orders as just that. To stress the fragility of conventional morality is therefore to shake the foundations of the manifest illegality rule. ${ }^{62}$

The manifest illegality provision provides legal basis, within the Rome Statute, 434 for thinking that basic moral perception is required for criminally responsible agency under this body of law.

In the end, inclusive legal positivists can acknowledge that law and morality are bound up with one another under international criminal, and that an implication of this is that persons need some basic moral perception to be capable of perceiving the moral norms that give force to legal prohibitions under this body of law. In light of this, perhaps a positivist, and a proponent of the Kantian-based version of the choice theory, could be persuaded to embrace the harmed moral perception excuse that I laid out above at the end of Section 2, and elaborate on below, at least as applied to international criminal law.

Insofar as the ICC expresses a moral voice of the international community, it represents the community of people, communities, and states who have a basic shared perception of where jus cogens norms apply in practice. Even if states and legal scholars debate the content and scope of these norms, the Rome Statut $\bar{m}$ anifest illegality provision identifies prohibitions on crimes against humanity and genocide as non-derogable, and therefore as having the status of jus cogens norms for the purposes of the Statute. Because the manifest illegality provision implicitly creates the requirement that persons under the ICC's jurisdiction need the capacity to perceive where these norms apply in particular situations to be capable of criminally responsible choice under Statute, and the fac $m$ ral perception is constitutive of one's basic moral character, the ICC is necessarily concerned with the basic moral characters of persons under its jurisdiction. ${ }^{63}$

So, what constitutive part of a person's moral character allows him or her to be capable of perceiving where the basic moral norms of international criminal

62 Mark Osiel, Mass Atrocity, Ordinary Evil, and Hannah Arendt: Criminal Consciousness in Argentina's Dirty War (Yale University Press, New Haven, CT, 2001), p. 151.

63 One reason Antony Duff, supra note 37, has argued that we do not want an Aristotelian criminal law is based on the view that it is not properly the business of the liberal state to evaluate persons' characters. Jonathan Jacobs argues in response that the liberal polity crucially depends on certain basic character traits being widespread, supra note 23 . My analysis here seeks to show that Jacob's point applies a fortiori to the international community. 
law apply in practice? I put forth 'ordinary moral perception' as the capacity that equips a person with this ability. As noted in the previous section, moral perception bridges the gap from abstract moral rules or principles to particular situations, and allows us to see ourselves living in a moral world where abstract moral rules and principles apply to the messy affairs of real life. ${ }^{64}$ Ordinary moral perception, as I construe it, is simply the capacity to perceive where the most basic moral norms (or jus cogens norms) apply. Consider, again, the wanton killing of innocent civilians, which is a crime against humanity if carried out as a part of a widespread and systematic attack. ${ }^{65}$ Having ordinary moral perception, or the moral perception of which an ordinary person is capable, would allow a person to see such instances as wrong, and as manifestly unlawful, in particular situations. ${ }^{66}$

If ordinary moral perception is needed to perceive where moral norms of international criminal law apply in concrete cases, then someone who suffers from a substantial non-culpable impairment to this capacity, while inside the forcibly limited and hostile environment of armed conflict, where the prudential reasons to choose to obey the law are considerably weak, cannot reasonably be expected to perceive the wrongfulness of the sphere of conduct deemed criminal under international criminal law. In such a case, I argue that a person warrants an excuse from criminal responsibility, on the grounds that he or she was deprived of the fair opportunity to choose to obey the law. This is the ba is i dea of the harmed moral perception excuse, and in the next section, I identify four conditions for the application of this excuse to a particular case, and then I examine a plausible case currently at the ICC, where it might be applied. Criminal Law

There are four conditions required to trigger the harmed moral perception excuse:

I. A person has a substantially limited capacity for ordinary moral perception, as a result of environmentally induced defective moral development.

64 Blum, supra notes 1 and 35 .

65 Rome Statute, Article 7.

66 Simply knowing that others think that certain conduct is wrong is not moral perception as such, though it would be enough (in most circumstances) for a person to know that the behaviour is considered manifestly unlawful. 
II. The person cannot reasonably be held to have culpably contributed to 491 having this agential defect to his or her moral perception, insofar as the 492 conditions under which it developed are recognised as excusing condi- 493 tions under the law.

III. He or she cannot reasonably have been expected to revise this defect before the time of action, due to having been in circumstances that greatly burden the ability to do so.

IV. It must be reasonable to regard the person's wrongful conduct as the result of the inability to see the conduct as wrong.

Where these conditions are met, a person has been deprived of the fair opportunity to choose to obey the law, and thereby warrants an excuse from criminal responsibility for violating it. So, what sort of case, then, would plausibly implicate the harmed moral perception excuse?

Consider the case of Dominic Ongwen, who is currently facing ICC prosecution for 70 counts of international crimes. Ongwen is a former leader of the notorious armed group from Uganda, the Lord's Resistance Army (LRA). ${ }^{67} \mathrm{He}$ is accused of 70 counts of crimes against humanity and war crimes, including: directing attacks against the civilian population, murder, torture, cruel treatment, outrages upon personal dignity, forced marriage, rape, torture, and sexual slavery. ${ }^{68}$ On the surface, Ongwen is an archetypal candidate for blame. He rose through the ranks of the LRA to become a Brigade Commander of one of the LRA's most destructive units. Yet, upon reflection, Ongwen's story is far more complex.

Ongwen not only is the youngest individual and lowest-ranking individual indicted by the ICC, but he is also the only person indicted by the Court for the same crimes of which he was a victim. ${ }^{69}$ Sometime between the ages of nineand-a-half and 13 years old, Ongwen was abducted by the LRA on his way to school..$^{70}$ Abduction is typical for the LRA, and the group often uses a method

67 For related inquiries into Ongwen's culpability, see Erin K. Baines, 'Complex political perpetrators: reflections on Dominic Ongwen', 47 Journal of Modern African Studies (2009) 163-191; Windell Nortje, 'Victim or villain: Exploring the possible bases of a defence in the Ongwen case at the International Criminal Court', 17(1) International Criminal Law Review (2017) 186-207; Mark Drumbl, 'Victims who Victimise', 4 London Review of International Law (2016) 217-246.

68 'Accused crimes (Non-exhaustive list)', International Criminal Court website, $<$ www.icccpi.int/uganda/ongwen/pages/alleged-crimes.aspx>, accessed 8 February 2019.

69 See Baines, supra note 67.

70 Ongwen's defence identifies nine and a half as his age of abduction, whereas the prosecution identifies twelve to thirteen. Prosecutor v. Dominic Ongwen, Case No. ICC-02/0401/15, Confirmation of Charges, p. 3, paras. 11-13 (26 January 2016). 
known as 'press-ganging', which is a 'form of group abduction wherein soldiers sweep through marketplaces or streets rounding up youths like fish in nets, or raid institutions such as orphanages or schools.' ${ }^{71}$ After Ongwen's abduction, he was placed under the tutelage of LRA leader, Vincent Otti, and trained to be a child soldier. While public information about Ongwen's specific experiences in the LRA is limited, typical experiences of LRA child soldiers are well documented, which allows us to understand what it is reasonable to expect Ongwen experienced.

During or soon after recruitment, LRA child soldiers endure initiation rituals where new recruits are forced to publicly kill a friend or family member under credible threat of immediate execution. ${ }^{72}$ This is done in public so newly abducted children witness other children refuse and be immediately executed or kill an innocent person and save their lives. After the initial steps of initiation, some children are then coerced to drink the blood of their deceased victims or hack their bodies to pieces, to desensitise them to the violence and brutality that will soon become the norm in their lives. Again, children who refuse suffer severe punishment, and even death.

Leaders then mutilate the bodies of new recruits in visible ways, on the face, for example, to create stigmatic markers that they are now members of the LRA. Practices such as these serve to morally sever child soldiers from their previous lives, before physically separating fro their any semblance of ordinary society. After initiation, the LRA brings cnidren into the 'bush', or the isolated jungle, for training, which consists of rigid physical and psychological tests that are met with severe penalties for refusing to participate or showing signs of weakness and sadness.

Moving from recruitment to modes of retention, ethnographic studies recount that many former LRA child soldiers explain that they had lar ied to follow the rules or consent to being killed. ${ }^{73}$ To prevent child recruits rrom escaping, the LRA is known to put children into a chain gang, using a chain made from barbed wire, so that the children would need to cut through their own limbs in order to get free. ${ }^{74}$ Other children are killed by the LRA while trying

71 Michael Wessells, Child Soldiers: From Violence to Protection (Harvard University Press, Cambridge, MA, 2006), p. 41.

72 Ibid., p. 14.

73 Opiyo Oloya, Child to Soldier: Stories from Joseph Kony's Lord's Resistance Army (University of Toronto Press, Toronto, 2013).

74 PBS Documentary, The Reckoning: The Battle for the International Criminal Court (Skylight Pictures, 2009). 
to escape, and many die during raids of villages or clashes with government $\quad 550$ forces.

Children who survive are subjected to a strict regime of training. Like ordinary soldiers, LRA child soldiers are put in uniforms and given war names but, unlike ordinary soldiers, among whom camaraderie is encouraged, LRA lead554 ers deliberately undermine the formation of trust among new child recruits. To 555 achieve this, the LRA institutes a policy where 'talking with other new recruits 556 is a punishable offense.. ${ }^{75}$ Michael Wessells explains that training aims to break the children's wills: '[t]ypically the training agenda is not to develop military or survival skills but to break children's will and to achieve high levels of dominance and control. ${ }^{76}$ He adds that:

Children are pliable in that they are flexible and easily manipulated and controlled. Young children are controllable through terror and brutality, a point not lost on older, stronger, and more cunning commanders. Through violence or threat of violence, young children can be trained to obey commands that many adults would contest or find ways around. ${ }^{77}$

One of the most brutal, systematic, and enduring tactics used by LRA leaders in their quest to coercively indoctrinate child soldiers into the values of the group is that they reward wanton acts of violence against innocents, and punish expressions of sadness, sympathy or compassion at the suffering of others.

The isolation and deliberate undermining of trust, combined with the brutal punishments and psychologically invasive forms of socialisation and indoctrination, can explain how children who enter the LRA unwillingly later become willing participants in the groups' activities. According to Wessells, 'Children who grow up having learned fighting as their only means of livelihood and survival are likely to continue fighting for more years than adults' ${ }^{78}$ One LRA commander explained in an interview that this is part of the LRA's plan, as children make better soldiers than adults:

It was easy to make the newly abducted children participate with us. We taught them to become loyal and do what we said. They listened. This was 579 difficult with grown-ups; we could not change their minds easily. They

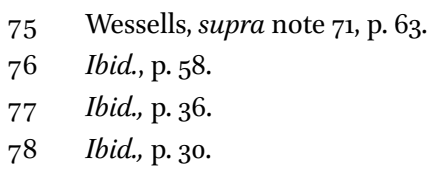


were always thinking about going home to their families. It was much easier to make the children become good, integrated rebels. ${ }^{79}$

Not all children become good, integrated rebels, although many do. In describing the diversity of responses among child soldiers in extreme armed groups more generally, Wessells observes that:

Some child combatants fight reluctantly, kill only when necessary, and constantly look for escape opportunities, whereas others learn to enjoy combat and redefine their identities as soldiers. A small minority become hardened perpetrators who relish the sight and smell of blood or initiate or participate willingly in atrocities that no one ordered them to commit. ${ }^{80}$

Counterintuitively, children who become hardened perpetrators and who participate willingly in atrocities no one orders them to commit may, in fact, be the most harmed by their experiences.

In Pre-Trial proceedings in Ongwen's case at the ICC, his defence team has argued that Ongwen should have his criminal responsibility excluded on the grounds that, from the time he was abducted until the time he surrendered, his status remained that of a child soldier under 15 , and a victim, under international criminal law. The Pre-Trial Chamber rejected this argument:

The Defence has raised several times an argument that circumstances exist that exclude Dominic Ongwen's individual criminal responsibility for the crimes that he may otherwise have committed. One side of this argument is that Dominic Ongwen, who was abducted into the LRA in 1987 at a young age and made a child soldier, should benefit from the international legal protection as child soldier up to the moment of his leaving of the LRA in January 2015, almost 30 years after his abduction, and that such protection should include, as a matter of law, an exclusion of individual criminal responsibility for the crimes under the Statute that

Scott Gates, 'Why Do Children Fight: Motivations and the Mode of Recruitment', in A. Özerdem and S. Podder (eds.), Child Soldiers: From Recruitment to Reintegration (Palgrave Macmillan, London, 2011), p. 45.

8o Wessells, supra note 71, p. 74 . 
he may have committed. However, this argument is entirely without legal basis, and the Chamber will not entertain it further. ${ }^{81}$

The driving force behind the Pre-Trial Chamber's rejection of the Defense's argument is the lack of a clear legal nexus between Ongwen's childhood victimisation and his adult crimes. ${ }^{82}$ In what follows, I articulate a legal nexus between Ongwen's background and his adult criminal conduct, in the course of illustrating a plausible application of the harmed moral perception excuse's four necessary conditions to his case.

To begin applying condition I to Ongwen's case, recent research in moral psychology shows that typical experiences of child soldiers in extreme armed groups like the LRA create a substantial risk of harm to the adult development of moral agency, especially to the capacity of moral perception. ${ }^{83}$ Aristotle recognised what contemporary moral psychology now confirms: the habits of feeling that we develop during our youth become settled parts of our characters as adults, and shape our adult moral perception. Indoctrination that involves rewards for wanton acts of violence and punishments for showing compassion at the suffering of others are precisely the kinds of experiences that create a substantial risk of harm to the developing child's emotional development, especially to the development of the moral emotions: guilt, shame, and empathy. ${ }^{84}$ Empirical work shows that child soldiers from extreme armed groups like the LRA suffer severe emotional disturbance as a result of their experiences, ${ }^{85}$ and insofar as emotion influences moral perception, ${ }^{86}$ these

81 The Prosecutor v. Dominic Ongwen, supra note 70, Decision on the defence request for leave to appeal the decision on the confirmation of charges, 26 April 2016. para. 18.

82 See Nortje, supra note 67, pp. 11-12.

83 Souris, supra note 60.

84 Katz and Scheutz-Mueller describe this as a 'hijacking' of the moral development of child soldiers: Craig L. Katz and Jan Schuetz-Mueller, A Guide to Global Mental Health Practice: Seeing the Unseen (Routledge, New York, 2015), p. 99.

85 Kennedy Amone-P'Olak and Bernard Omech, 'Coping with post-war mental health problems among survivors of violence in Northern Uganda: Findings from the wAYs study', Journal of Health Psychology (2018), <doi.org/10.1177/1359105318775185>, accessed 8 February 2019. Research conducted with former child soldiers from the Revolutionary United Front (RUF), an armed group from Sierra Leone notorious for practices like the LRA, finds strong indicators of emotional disturbances associated with PTSD from child soldiering. See Theresa Betancourt et al., 'Sierra Leone's former child soldiers: A longitudinal study of risk, protective factors, and mental health', 49(6) Journal of the American Academy of Child \& Adolescent Psychiatry (2010) 606-615.

86 Daniel Jacobson, 'Seeing by Feeling: Virtues, Skills, and Moral Perception', 8(4) Ethical Theory and Moral Practice (2005) 387-409. 
emotional disturbances create a substantial risk of harm to the adult capacity for ordinary moral perception. Therefore, an adult who spent his or her formative adolescent years inside has likely developed environmentally induced defective moral development that manifests itself as a substantial limitation to his or her capacity for ordinary moral perception. This satisfies condition I noted above.

Moving to consider condition II, there are several reasons for thinking that someone who spent his or her formative years inside an extreme armed group like the LRA, and who grows up with a substantial limitation to his or her capacity for ordinary moral perception, cannot be held to have culpably contributed to having this defect, based on existing standards in the law. First, Article $3^{1}$ of the Rome Statute identifies duress ${ }^{87}$ as a full defense to criminal responsibility, and duress would provide a full defense for children under 15 who kill innocents to save their own lives, as children are forced to do during initial rituals with the LRA. ${ }^{88}$ The Statute further reflects the non-culpability of children under 15 by making the conscription or enlistment of children under 15 for active participation in hostilities a war crime. ${ }^{89}$ This shows that children under 15 cannot exercise responsible choice to consent to participate in armed conflict under the Statute, and this presumption of non-responsibility would need to extend to conduct inside armed conflict carried out by children under 15 for the Statute to be interpreted in a consistent way.

Secondly, there is reason to think that the best interpretation of the Rome Statute is one that regards the otherwise unlawful conduct of adolescents aged 15-17 inside armed conflict as non-culpable. Article 31(3) of the Rome Statute states that the Court may derive grounds for excluding criminal responsibility from the applicable law set forth in Article 21, which states that the Statute should be interpreted consistent with 'applicable treaties and the principles and rules of international law'. There is good reason to recognise the age of eighteen as the age of criminal responsibility under international law. The ICC only has jurisdiction over conduct performed after a person's eighteenth birthday, and the age of 18 has been adopted as the minimum age of responsibility in the Optional Protocol to the Convention of the Rights of the Child (2000) and in the Paris Principles (2007), the latter of which has been endorsed by over 100 countries worldwide. Beyond doctrine, the view that adolescents aged 15-17 are non-culpable for conduct inside armed conflict is also reflected

\footnotetext{
87 Rome Statute, Article 31(1)(d).

88 Matthew Happold, 'Child Soldiers: Victim or Perpetrators', 29 University of La Vern Law Review (2008) 56-87.

89 Rome Statute, Article 8(e)(7).
} 
in practice, as no international court has held persons under 18 criminally responsible for their participation in mass atrocities.

Thirdly, Article 31 of the Rome Statute broadens the scope of duress to include not only immediate threats by others, but also the 'threat of imminent death or of continuing or imminent serious bodily harm', where the threat one acts to avoid is either 'made either by other persons' or 'constituted by other circumstances beyond that person's control'. While there are other parts of the provision that must be satisfied for the defense to apply, which the Pre-Trial Chamber judges have rightly interpreted would not be satisfied in a case like Ongwen's that involves the killing of innocents, the provision provides a legal basis for thinking both that certain kinds of environments unfairly burden a person's agential capacities, and that one's presence inside such environments may be largely beyond his or her control. Based on the specific formulation of duress in the Rome Statute, I argue there is legal basis for recognising the nonculpability of the kind of defective moral development that can result from child soldering in an extreme armed group like the LRA.

If, by the time Ongwen was a young adult, he had spent his formative years subject to episodic threats of death or serious bodily harm made by his superiors inside the LRA, within the larger environment of armed conflict that poses continuing threats outside the group, then it is reasonable to say his circumstances were largely beyond his control. Moreover, even if he was no longer exposed to imminent threats from superiors for acting against the group's interest, he might reasonably expect otherwise, or simply not want to take the risk by supposing that it is not. Depending upon the particular experiences to which Ongwen was subject, his practical reasoning and his perception of right and wrong may be so distorted that he may be substantially limited in his ability to calibrate risk and reward, and to see the wrongfulness of his conduct, through no fault of his own, insofar as the conditions under which these defects developed are recognised as non-culpable under standards contained in the law. This, then, would satisfy condition II.

This brings us to condition III. Because Ongwen remained in the forcibly limited and hostile environment of armed conflict into young adulthood, is it also reasonable to think that, by the time he was a young adult, he was substantially limited in his capacity to exercise the kind of reflective self-control ${ }^{90}$ that would allow him to critically assess what he was taught, in light of moral rules and principles and abandon the strategies he learned to survive as a child. Even if he was not, in principle, completely incapable of perceiving how basic moral 
norms apply to his situation, it is reasonable to expect that his ability to do so would be substantially and unfairly diminished while in this environment. The environment of armed conflict is known to burden an ordinary person's capacity for moral perception and practical reasoning, making it unreasonable to expect a person with harm to these capacities to exercise the kind of reflective self-control that would be needed to revise his or her character. Because of the continuing threats facing Ongwen into his adulthood, and his substantially impaired capacities to make sense of these threats, he could not reasonably have been expected to revise the agential defects to his character, before the time of action at issue in his alleged crimes at the ICC, thereby satisfying condition III.

Moving, lastly, to condition IV, consider the fact that, until his surrender, Ongwen's life was lived mostly in isolation in the African jungle, lacking socialisation with people who were not also in the LRA. If Ongwen grew up in an environment where those who challenged the values and practices of the LRA were punished or killed, it is plausible that he may not ever have socialised with a person who expressed the wrongfulness of the atrocities the group is known to commit. Depending on the degree of his isolation from law-abiding society, combined with the invasiveness and depth of his indoctrination, it is possible that he may not have recognised that others consider his conduct wrongful, even as a matter of social fact.

Ongwen only came to question the LRA when top LRA leader, Joseph Kony, had Vincent Otti killed. To recall, Ongwen lived in Otti's home during his time as a child soldier, and it is likely he came to see Otti as a gatekeeper of his security. If Ongwen regarded Otti's murder as a threat to his own security, this could explain why, after years of embracing the LRA, he came to question Kony and the LRA. When Kony heard that Ongwen was considering leaving the LRA, Kony had Ongwen detained and tortured. ${ }^{91}$ Ongwen was able to escape detention under Kony, after which he fled the LRA and surrendered to a cattle herder, who brought him to the nearby Seleka rebel group in the Central African Republic. ${ }^{92}$ Because Ongwen came to challenge the LRA when his own security was at stake, it is reasonable to think that he did not perceive the wrongfulness of his conduct while inside the group, and if this is true, then it is reasonable to regard his wrongful conduct as the result of the inability to see the conduct as wrong, thereby satisfying condition IV.

Although Ongwen has been accused of gross atrocities, it is unclear that he is truly the kind of evil mastermind that the ICC was designed to punish. What is clearer is that there is good reason to question Ongwen's culpability, if his

$91 \quad$ Nortje, supra note 67.

92 Ibid. 
developmental background was littered with the kinds of traumatic experi- $\quad 740$ ences that are typical of LRA child soldiers. If Ongwen, or persons like him, are $\quad 741$ substantially and non-culpably limited in their capacity for ordinary moral per- $\quad 742$ ception, in environments where the prudential reasons to choose to obey the $\quad 743$ law are weak, and where the applicable legal rules derive their force from moral $\quad 744$ norms, they have been deprived of the fair opportunity to choose to obey the 745 law. In such cases, persons warrant an excuse from criminal responsibility for $\quad 746$ prohibited conduct they performed under the specified limited conditions. ${ }^{93} \quad 747$

In this article, I have contributed to the debate between two philosophical traditions - the Kantian and the Aristotelian — on the requirements of criminal responsibility and the grounds for excuse by taking this debate to the context of international criminal law. After laying out broadly Kantian and Aristotelian conceptions of criminal responsibility, I defended a quasi-Aristotelian conception, which affords a central role to moral development, especially to the development of moral perception, for international criminal law. My defense relied on the environments in which international crimes typically occur, and the moral nature of international crimes.

Under the quasi-Aristotelian conception of criminal responsibility and excuse that I drew on in this article, a person is excused from criminal responsibility if she lacked either the capacity or the fair opportunity to choose to obey the law, where this includes the capacity for practical reason, as well as certain moral capacities, and a fair opportunity to exercise these capacities. I then showed that an implication of this view is that certain forms of non-culpable defective moral development ground an excuse from criminal responsibility, and I introduced the harmed moral perception excuse as a particularly relevant excuse for international criminal law. From here, I identified four conditions that are needed for the excuse to apply and I examined the case of Dominic Ongwen currently at the ICC as an example of where the excuse might apply. With this summary in view, I now offer a few concluding reflections based on my analysis.

93 I recognise that persons like Ongwen may be dangerous, and that incapacitation on utilitarian grounds may be morally justifiable. To embrace this is not to concede responsibility, but rather it is to recognise our obligations to protect innocent people. For incapacitation to be morally permissible, further conditions need to be met, including the minimum deprivation necessary, and the provision for rehabilitative support. 
For those who remain hesitant in excusing someone like Ongwen under the criminal law, Gary Watson offers a distinction between two kinds of blame that is helpful in making sense of tension we may have in this sort of case. ${ }^{94}$ Watson distinguishes between two 'faces' or kinds of responsibility: on the one hand, there is an aretaic or attributability face to our practices, where we judge others, and are judged by them, in light of 'ideals of human excellence,' and, on the other hand, there is an accountability face, which deals with 'social regulation' and 'retributive and compensatory justice. ${ }^{95}$ While aretaic blame is appropriately expressed toward defects in one's character and is limited in its response to the expression of a negative attitude toward another person, accountability blame calls for something further-the imposition of sanction.

Because accountability blame calls for the imposition of sanction, it is constrained by principles of fairness, which require that sanctions are only imposed for conduct that persons could have reasonably been expected to avoid, and by someone with legitimate authority to impose the sanction, or to use Watson's phrase, 'someone authorized to the make the demand. ${ }^{96}$ As the criminal law has a monopoly on imposing legal sanction, and criminal courts are vested with the authority to impose sanctions, the criminal law is concerned with the accountability face of responsibility. Using the distinction between aretaic and accountability blame, Watson argues that we can judge a person to be defective in relation to ideals of human excellence and wish to express this judgment by expressing aretaic blame, even if we conclude that fairness renders the person unfit for accountability blame in the form of criminal sanction.

Aretaic blame is appropriate for character defects in an agent, against ideals of human excellence, and, obviously, persons like Ongwen are unworthy of emulation. This may perhaps be especially so, relative to the various children who sacrificed their lives in acts of disobedience to leaders who sought to coercively mould them into pliant child soldiers. We might even wish to praise such children as courageous, or as standing up against injustice, if they refused to harm others to save their own lives, which is reasonable, as long as our praise does not develop into the highly problematic notion that children ought to sacrifice their lives in such circumstances.

By appreciating the two faces of responsibility for a case like Ongwen's, we can begin to make sense of any internal tension that we may experience in our efforts to understand his case, and also the various, often conflicting,

94 Gary Watson, Agency and Answerability: Selected Essays (Clarendon Press, Oxford, 2004).

95 Ibid., pp. 285-286.

$96 \quad$ Ibid., p. 276. 
judgments of those who knew him throughout his life. Actual victims of Ongwen have expressed a long list of reactive attitudes toward him, from anger and resentment for the pain he caused, to sympathy and even gratitude for the kindness and the mercy of which he, at times, seemed capable. ${ }^{97}$ The fact that Ongwen is capable of displaying episodes of mercy shows that his moral capacities are not entirely destroyed, but it does not show that, after all, he was capable of criminally responsible choice. A person's capacity for ordinary moral perception does not have to be completely destroyed to warrant an excuse under the harmed moral perception excuse, ${ }^{98}$ but, rather, a reasonable expectation that a person's capacity for ordinary perception was substantially and unfairly diminished at the time of action is sufficient.

Adults who were recruited into extreme armed groups as children, and who, as a result, suffer from substantial limitations to their capacity for ordinary moral perception, stand at the margins of the moral community, but they should be provided with socially created opportunities to move more fully into the moral community. Fieldwork on the re-integration of former child soldiers highlights the resilience of children and adolescents, ${ }^{99}$ but because most rehabilitative programs exclude persons over 18 from access to their resources, adults who grew up as child soldiers are often neglected. Without support as they make the transition into their communities, and having spent their formative years in armed conflict, many are vulnerable to recruitment by governmental armies, and others who lack marketable skills turn to street crime to make a living.

The Rome Statute's Preamble acknowledges that millions of children have been victims of 'unimaginable atrocities that deeply shock the conscience of humanity' and it refers the bonds between peoples and cultures as a 'delicate mosaic' that 'may be shattered at any time.100 Virtue ethics and contemporary moral psychology teach us that each child is also a delicate mosaic, who is vulnerable, just as much as he or she is resilient, and whose moral perception may be harmed by the unimaginable atrocities of child soldiering. Not

97 Drumbl, supra note 67; see also Nortje, supra note 67, citing Baines, supra note 67, p. 175.

98 As would be required if he were to be excused under the mental disease and defect provision in Article 31(1)(a) of the Rome Statute, which identifies, as a ground for exclusion of criminal responsibility that: ' $[\mathrm{t}\}$ he person suffers from a mental disease or defect that destroys that person's capacity to appreciate the unlawfulness or nature of his or her conduct, or capacity to control his or her conduct to conform to the requirements of law' (emphasis added).

99 See Souris, supra note 6o.

100 Rome Statute, Preamble. 
836 all child soldiers are traumatised by their experiences, but many are, and we 837 should take seriously the reality that those who appear most hardened by their 838 experiences may also be the most traumatised by them. Unless we do so, I 839 worry that our efforts at ending impunity for atrocities will only contribute to 840 more injustice. ${ }^{101}$

841

101 I would like to thank anonymous reviewers from the journal for the helpful comments on my article, as well as my friend and colleague Jeffrey Turner, for discussing the philosophical issues at stake in my argument. 